УДК 328.14(477)

(C) 2015

Опара Н. М., кандидат сільськогосподарських наук

Полтавська державна аграрна академія

\title{
ПРОБЛЕМНІ ПИТАННЯ ВИКЛАДАННЯ БЖД У ВНЗ УКРАЇНИ
}

\section{Рецензент - кандидат технічних наук С. П. Школяр}

У статті висвітлюються актуальні питання дискусійних проблем, що виникають у проиесі викладання дисичиллін "Безпека життєдіяльності», "Охорона праці», «Цивільний захист», «Охорона праці в галузі». Проведений аналіз останніх наукових публікацій 3 даного питання, вказується на негативи, щзо виникають під час переведення вивчення вищеназваних дисциилін з категорії нормативних у категорію «за вибором»; показані можливі иляхи їх усунення.

Ключові слова: безпека життєдіяльності, циивільний захист, охорона праці, узагальнення, аналіз, нормативні дисиипліни, реформування, типові програми, навчальні плани.

Постановка проблеми. Останнім часом у вищих навчальних закладах України спостерігається низка дискусійних проблем, пов'язаних 3 викладанням наступних дисциплін: «Безпека життєдіяльності», «Цивільний захист», «Охорона праці», «Охорона праці в галузі».

Все це пов'язано з реформуванням вищої освіти, прийняттям нової редакції Закону України «Про освіту», а також низкою інших не менш важливих документів.

Аналіз основних досліджень і публікацій, у яких започатковано розв'язання проблеми. У наукових працях фахівців з БЖД, ЦЗ, ОП, ОПГ із проблем викладення цих дисциплін у ВНЗ України (В. М. Заплатинський, В. Терещенко, О. I. Запорожець) неоднозначно висвітлюються питання реформування освіти в галузі вищеперелічених дисциплін, що й спонукало автора до написання даної статті.

Мета досліджень - узагальнити матеріали публікацій стосовно викладання БЖД у ВН3 України.

Основне завдання - деталізація основних проблемних питань щодо даної теми.

Результати досліджень. За підсумками аналізу публікацій у фахових виданнях було зроблено наступний аналіз останніх публікацій 3 висвітлюваного питання.

В травні 2014 року Кабінетом Міністрів України було скасовано спільний наказ МОН, МНС і Держгірпромнагляду «Про організацію та вдосконалення навчання 3 питань охорони праці, безпеки життєдіяльності та цивільного захисту у вищих навчальних закладах України» від 21.10.2010 № 969/922/216.

Як же це вплинуло на обсяг викладання згаданих дисциплін у вищих навчальних закладах України?

Редакцією науково-виробничого журналу «Охорона праці» було проведено анкетування респондентів. Анкета містила три питання: «Чи є у Вашому виші кафедра з вивчення питань охорони праці?», «Що змінилося після скасування спільного наказу?», «Чи включений розділ «Охорона праці» у дипломні роботи бакалаврів $\mathrm{i}$ магістрів?»

Дев'ятнадцять українських вишів відповіли, що нічого не змінилося, робота в 2014-2015 навчальному році триває за раніше затвердженими планами.

Майже всі відповіді свідчать про те, що скасування спільного наказу істотно не вплинуло на формування навчальних планів на 2014-2015 навчальний рік. У більшості вузів це пояснюється тим, що наказ скасували вже після планування навчального навантаження.

Проведення анкетування показало, що у 16-ти з 19-ти вишів є спеціалізовані кафедри.

Якісний склад кафедр: знання студентам передають 28 докторів і 123 кандидати технічних наук. Це величезна армія фахівців, яка вже сьогодні робить усе, щоб гарантувати безпечну працю на виробництві на багато років уперед.

Актуальність вивчення дисциплін «Безпека життєдіяльності», «Цивільний захист», «Охорона праці», «Охорона праці в галузі» в межах навчального процесу у ВН3 в сучасних умовах обгрунтовувалася ще в 1985 році і не викликає сумнівів.

У зв'язку з тим, що в програмі загальноосвітньої школі був виключений предмет «Основи безпеки життєдіяльності», а у програмі предмету «Захист Вітчизни» на вивчення питань сфери цивільного захисту виділена недостатня кількість навчального часу, була порушена послідовність і наступність навчання - «від простого до складного».

Студенти першого курсу ВН3 не мають достат- 


\section{TEХНIЧНI НАУКИ}

нього рівня знань (за результатами знань, отриманих у загальноосвітній школі), необхідних для якісного засвоєння програми дисципліни «Безпека життєдіяльності».

Студент другого курсу ВНЗ, якщо i освоїв програму «БЖД», до п’ятого курсу навчання успішно втрачає більше 80 \% знань, навіть за якісних міжпредметних та міжкафедральних зв'язках, необхідних для якісного засвоєння дисципліни «Цивільний захист».

У рамках навчального процесу, що відводиться на вивчення дисциплін БЖД та ЦЗ, за такого розмежування в часі вивчення, досягнення цілей, поставлених програмами дисциплін, у кращому випадку маловірогідно [4].

Ситуація, що склалася в країні в останній рік, особливо у зоні проведення антитерористичної операції, вимагає нових підходів і у викладанні низки дисциплін.

У типових програмах вищеперелічених дисциплін у прямій постановці не розглядаються питання оповіщення та інформування населення у разі надзвичайних ситуацій, евакуації (населення, матеріальних, культурних та інших цінностей), що в подальшому негативно позначилося на розробці робочих програм з дисциплін.

Спеціальна література, що існує на сьогодні у масовому виданні за дисциплінами БЖД, ЦЗ, ОП, ОПГ, розрізнена, розрахована на різний рівень використання і лише в разі системного використання Інтернет-джерел дає змогу засвоїти у повному обсязі програми дисциплін [2].

12 грудня 2014 року у місті Києві відбувся Всеукраїнський семінар завідувачів кафедр та фахівців з безпеки життєдіяльності та цивільного захисту.

Проведення семінару було ініційовано дорадчою науково-методичною радою «Безпека життя і діяльності людини» МОН України.

Своєчасність цього зібрання була обумовлена рішенням 3 2015/2016 навчального року перевести вивчення дисциплін БЖД, ЦЗ, ОП, ОПГ з категорій нормативних у категорію «за вибором», а також збільшенням кількості кредитів дисциплін, що вивчаються, з 1,5 до 3-х.

Фахівці звернули увагу на те, що викладачі кафедр Охорони праці не братимуть участі у засіданнях екзаменаційних комісій, це призведе до того, що кількість викладачів кафедр в середньому зменшиться у півтора рази.

Багатьох викладачів можуть перевести на 0,5 ставки, а тих, у кого закінчується строк дії контракту із вишем, його можуть не продовжити.

Якщо враховувати рівень травматизму у тому числі й смертельного, на підприємствах АПК, штат викладачів з Охорони праці необхідно збільшувати, а не зменшувати.

У деяких ВНЗ розділ «Охорона праці» включений лише до дипломних проектів на технічних спеціальностях.

Навіть у спеціалізованих ВНЗ Департаменту 3 надзвичайних ситуацій України вивчають способи подолання лиха, а не їх запобігання.

У студентів мають місце низький рівень знань, вмінь та певних навичок самостійної роботи та подекуди слабкий рівень комп'ютерної підготовки [4].

Має місце мала зацікавленість студента в отриманні знань (наукові завдання творчого характеру, розробка проектів, презентацій, використання різноманітних методів перевірки знань).

У вкрай стислі терміни розглядаються питання, на освоєння яких необхідно значно більше навчального часу.

На лекції та практичні заняття 3 предмету відводиться однакова кількість навчального часу.

Недостатня кількість часу, що відводиться на профільну підготовку, іiі недостатня спрямованість [1].

\section{Висновки:}

1. Оскільки навчальні плани розробляються згідно з Галузевими стандартами вищої освіти, за напрямками підготовки не змінювалися, то й кількість годин на вивчення зазначених предметів повинна залишитись колишньою і ні в якому разі не змінюватися.

2. Курс БЖД може бути реформований, доповнений $з$ урахуванням спеціалізації ВН3 або напряму підготовки студента.

3. Курс БЖД не повинен скорочуватися або інтегруватися в інші дисципліни, тому що кількість небезпек, що загрожують сучасній людині, постійно збільшується. У нинішній соціальнополітичній обстановці в країні таке скорочення годин, відведених на вивчення дисциплін, які дають студентам життєво необхідну інформацію щодо дій у разі виникнення небезпеки різного походження, можна розглядати як загрозу національній безпеці України в цілому.

4. Неприпустимо в технічних ВНЗ проводити скорочення часу навчальних програм 3 дисциплін БЖД, ЦЗ, ОП, ОПГ.

5. Неприпустимо проводити суміщення вказаних дисциплін в одну дисципліну - БЖД 3 одним заліком або іспитом.

6. Необхідно ввести у всі дисципліни інженерно-технологічного факультету наступні теми:

- охорона праці під час проведення технічних процесів;

- охорона праці під час експлуатації машин, 
механізмів, обладнання.

7. У дисципліни, які розглядають питання проектування об'єктів, конструювання машин, механізмів, обладнання тощо, необхідно ввести теми щодо вимог безпеки під час проектування відповідних об'єктів і вимог безпеки до будови відповідних машин, механізмів тощо.

8. Виконання цих вимог передбачено низкою законів, стандартів, правил та інших нормативно-правових документів з охорони праці та промислової безпеки України, прийнятих в установленому порядку відповідних міжнародних документів.

9. Наявність розділу з охорони праці в дипломних роботах випускників дає змогу студентам

\section{БІБЛІОГРАФІЯ}

1. Заплатинський В. М. Перспективи науки та освіти з безпеки життєдіяльності / В. М. Заплатинський // Безпека життєдіяльності. - 2007. №4. - С. 4-5 .

2. Биков В. I., Кожем'якін О. С. Удосконалення процесу викладання дисципліни «Безпека життєдіяльності» у вищих закладах освіти / В. І. Биков, О. С. Кожем'якін // Безпека життєдіяльності. - 2007. - №8. - С. 38-39. реалізовувати набуті теоретичні знання, формуючи вимоги 3 охорони праці для технологічних процесів або конструкційних розробок. Та й у бізнес-планах, на розробку яких у дипломних роботах зроблено особливий акцент, має бути врахована необхідність виділення коштів на заходи $з$ охорони праці, як це передбачається ст. 19 Закону України «Про охорону праці», оцінений соціально-економічний аспект від їх впровадження, окреслені джерела фінансування. За такого підходу випускник матиме авторитет не тільки як фахівець аграрного виробництва, а й як фахівець високого рівня, який не лише турбується за культуру виробництва та здоров'я інших працівників, а й знає, як цього досягти [3].

3. Терещенко В. Плоди зберемо восени / В. Терещенко // Охорона праці. - 2015. - №4. - С. 28-29.

4. Вірченко T. Питання щодо реалізації типових навчальних програм з нормативних дисциплін «Безпека життєдіяльності», «Цивільний захист» у вищих навчальних закладах I-III рівнів акредитації / Т. Вірченко // Безпека життєдіяльності. - 2013. - №9. - С. 11-12. 